\title{
Tourism development of Siberia
}

\begin{abstract}
The article is devoted to the Siberian spaces as a kind of biosphere-therapeutic and freshwater reserve of the globe. Most of Russia's neighbors are residents of warm and hot countries with snowless winters. The article suggests for them a completely different form of relaxation in Siberia. Cold and insurmountability are becoming less and less obstacle for tourists. And at the same time, with the increasing complexity of the technosphere there is a simplification of its diversity and the risk of a catastrophic outcome. That is why it is so important to maintain and develop obsolete technologies and archaic. Only tourism can save all kinds of archaic. Today's reality is such that the history, not being framed as a touristic product, is forgotten.
\end{abstract}

Keywords: tourism, biosphere-therapeutic and freshwater reserve, obsolete technologies and archaic, Siberia
Volume 4 Issue I - 2020

\section{Yu N Golubchikov}

Moscow State University, Faculty of Geography, Moscow, Russia

Correspondence: Yu N Golubchikov, Moscow State University, Faculty of Geography, Moscow, Russia, Email golubchiko@list.ru

Received: December 13, 2019 | Published: January 21, 2020

\section{Introduction}

The world economic center is rapidly approaching southern Siberia with the beginning of the $21^{\text {st }}$ century. ${ }^{1}$ Siberian spaces begin to play a special role in the world because they are geographically close to all the most powerful and most densely populated states of Western Europe, Asia and America. The demand for travel, recreation and treatment in an unpolluted environment, food with environmentally friendly products is constantly growing in them. Landscape tourism, naturopathy, holistic healing are becoming increasingly popular. People are increasingly attracted to places where nature has been preserved in almost pristine condition.

But not one of the countries has preserved such vast spaces with a pristine natural environment as Russia did in its northern and eastern possessions. This means that flying over them on an airplane or looking at pictures from space, it is not possible to detect any significant traces of human activity - settlements, roads, reservoirs, power lines, cultivated fields, even lights in the middle of the night. Contrary to the widespread ideas in the scientific literature and journalism about the destroyed nature of Russia, it owns 15\% of all areas of the Earth's land almost unaffected by human activity, $20 \%$ of the world's freshwater reserves. ${ }^{2}$

The global role of Siberia lies in the fact that it is a kind of biospheretherapeutic reserve of the globe. It is necessary to capitalize on this unique resource with the enormous potential of both organic farming and recreation in an ecologically clean environment. Recreational services are becoming more priority over material values and natural resources and serve the transition from the transformation of nature and its protection to the transformation of man and his salvation.

About 2-3 billion of the world's population with hundreds of millions of potential tourists are concentrated very close to Russia. First, it is a fast-growing China with completely reduced forests and environmentally unfavorable living conditions, even in rural areas. From here, it is easy to involve wide segments of the middle class of the population in low-cost types of tourism, unpretentious to sanitary and hygienic conditions and reaching for a solitary vacation in ecologically clean virgin nature in historically close, but unfamiliar spaces with inexpensive moving. With the railway exit of Siberia to the countries of the Indian Ocean, tourists from India and Pakistan will appear.

Most of Russia's neighbors are residents of warm and hot countries with snowless winters. They feel the need for a completely different form of relaxation than the Russians. Sunbathing at the resorts of Egypt or Turkey is uninteresting for a rich resident of Thailand. Relatively close to them, Russia introduces a completely different world. «Russia can be not only energetical, but also a tourist superpower» concludes Oleg Matveychev, professor at the Higher School of Economics. ${ }^{3}$

Cold and insurmountability are becoming less and less obstacle for tourists. Available light and warm clothes, means for repelling mosquitoes and midges, economical heating systems and heatinsulating building materials. With the rapid development of transport and network technologies, North is getting closer. ${ }^{4}$

And at the same time, the eruption of Iceland's Eyjafjallajokull volcano in 2010 showed how important the diversity of the transport system is for its stability. The eruption carried the ash to a height of $13 \mathrm{~km}$, and it hung for two weeks. This event significantly affected the work of jet aircraft. And the eruption of the volcano Krakatau in 1883 threw ash to a height of $80 \mathrm{~km}$, and it sagged in the atmosphere for three years. Had it happened these days, we would have to give up the jet aircraft.

With the increasing complexity of the technosphere there is a simplification of its diversity and the risk of a catastrophic outcome. All, for example, modern civilization hung on electricity. That is why it is so important to maintain and develop obsolete technologies and archaic such as steam locomotives, steamboats, carburetor cars, biplanes, sailboats, airships, balloons or riding horses, wood heating or water supply in wells. In critical mode, these types of equipment and their associated work skills can fulfill an unimaginable role. Their development and the creation of models of a new generation, perhaps even more important than all kinds of digital innovations. 
Meanwhile, each fundamentally new achievement of technological progress crosses out the development of its other areas, translated by more successful colleagues into symbols of technical backwardness. It is still unknown what success steam locomotive building would achieve if it were not completely excluded from development. Its history totaled almost 200years, when the last steam locomotive was built in Russia in 1956, and in China in 1988. The fact that retro-steam locomotive traffic is organized along the Circum-Baikal Railway is also important from a national security perspective. The same movements can be organized on the branches of the HSRW, all the way from the Indian Ocean to the Bering Strait.

Only tourism can save all kinds of archaic. Today's reality is such that the history, not being framed as a touristic product, is forgotten.

\section{Conclusion}

Siberia should benefit from its unique resource with tremendous opportunities for recreation in an ecologically clean environment. Recreational services in a renewed world are becoming more and more priority over material values and serve the transition from the transformation of nature and its protection to the transfiguration of man and his salvation. Tourism contributes to the revival of traditional environmental management and technological archaic. The preservation of labor skills and the traditional ways of life of the peoples of Siberia developed over millennia is important not only for the humanistic development of the world, but also from the perspective of the unknown, that humanity can wait in its everaccelerating movement toward an unknown goal.

\section{Acknowledgments}

None.

\section{Conflicts of interest}

The author declares that there is no conflict of interest.

\section{Funding}

None.

(Endnotes)

${ }^{1}$ Brakman S, Frankopan P, Garretsen H, et al. The New Silk Roads: an introduction to China's Belt and Road Initiative. Cambridge Journal of Regions, Economy and Society. 2019;12(1):3-16.

${ }^{2}$ Klyuev NN, Yakovenko LM. Ecological Geography of Russia: Nature Management at the Turn of the Century. Moscow: Russian Word; 2017; 96 p.

${ }^{3}$ Matveychev OA. What to do to Russia? Breakthrough strategies of the third millennium. Moscow: Eksmo; 2012. p.134.

${ }^{4}$ Golubchikov Yu N. Contemporary Periglacial Environment and its Humanitarian and Geographic Features. Kriosfera Zemli. 2015;XIX(3):3-8. 